\title{
Public space without architectural barriers as friendly and accessible for people with disabilities
}

\author{
Kamil Rawski \\ Department of Building Structures and Architecture, Faculty of Civil and \\ Environmental Engineering, Bialystok University of Technology
}

\begin{abstract}
Accessible public space for people with disabilities is the space where there are no barriers that prevent them from normal functioning in a given place. In this paper, there was collected a number of examples of most common barriers and design guidelines needed to plan or transform space into the accessible one. There was also described type of barriers and factors that affect on the accessibility of the public space.
\end{abstract}

Keywords: universal design, designing for disabled, accessibility, public space, architectural barriers

\section{Introduction}

An increasing number of people with disabilities is a significant problem. It has been noted that from year to year number of disabled people in the whole world are rising up. There are many factors that may be responsible for this situation. Among these are civilizational diseases, road and sport accidents, aging society, and psychological burden related to stress [Złowodzki 2008]. According to World Health Organization disabilities is an umbrella term, covering impairments, activity limitations, and participation restrictions. An impairment is a problem in body function or structure; an activity limitation is a difficulty encountered by an individual in executing a task or action; while a participation restriction is a problem experienced by an individual in involvement in life situations. Thus disability is a complex phenomenon, reflecting an interaction between features of a person's body and features of the society in which he or she lives [definition: www.who.int/topics/disabilities/en/]. Central Statistical Office of Poland (GUS) based on National Census of Population and Housing 2011 estimates, that in Poland about $12,2 \%$ people from the entire population have various dysfunctions, that is about 4,7 million people [Adach-Stankiewicz et al. 2012]. Of course, some of these dysfunctions do not interfere so much with normal functioning and are not conducive to the spread the phenomenon of social exclusion. Despite this, people responsible for spatial planning should include disabled people in designing process. Every person have the same right to use the public space, that is why barrier-free design is so important. However, the individual elements of space for one disabled can be an obstacle, and for others not. In order to better understand needs of people with disabilities, the knowledge about the types of their diseases is useful. The biggest problems with moving around the public space have people with: vision disabilities (blind, visually impaired), physical disabilities (moving in wheelchairs, chronic diseases of internal organs), hearing disabilities (deaf) and mental disabilities (cerebral palsy, mentally retarded) [Osman et al. 2015, Rawski 2017].

\section{Material and methods}

On the basis of Polish law and literature related to universal design and accessibility standards, there was defined architectural barriers in public space and types of them. There were also collected a number of guidelines 
for design new or transform already existing places in public space into more accessible for the people with disabilities. These guidelines were divided by their type and they concern parameters related to:

communication paths,

neight differences,

- space equipment,

- infrastructure associated to transport.

\section{Results and discussion}

\section{Designing for disabled}

Architectural barriers have very important influence to life quality of the people with disabilities. In many cases, the existence of such barriers hinders or even prevents them from using public services. Need of ensuring equality to all the people, including those with disabilities is mentions in Polish Constitution (Art. 30, 32, 68 and 69) and also the international normalizations. In 1982 "World Programme of Action Concerning Disabled Persons" was formulated and adopted by resolution of United Nations. This programme assumes meeting three major objectives:

- Prevention,

- Rehabilitation,

- Equalization of opportunities.

It was granted that tasks from these areas should be realized in many levels, involving many fields of knowledge, in particular technical, medical and humanistic and also in cooperation with different professionals like architects or town planners [United Nations 1982, Barczyński 2011].

One of the ways to meet mentioned aims is to design people's environment more ergonomic. As E. Tytyk [2001] stated, ergonomic design is the realization of such a design process, that creates the greatest chance of obtaining the project of human-technical object system with the desired level of ergonomic quality. Its primary purpose is to widen the range of mobility, perceptual, communication, and even intellectual abilities in the disabled people. Therefore, elementary ergonomic design aims were defined as:

a technical compensation for inability to normal function in society for disabled people,

- eliminating any external barriers (e.g. architectural) that hinder the daily existence of people with disabilities [Sprawny Fachowiec 2015].

Another trend in design that is strongly connected with ergonomic design is universal design. This term was first used in 1970's, but the idea was developing since early 1960's by architect Ronald L. Mace. Initially in North America and later on in Western Europe and other parts of the world. Generally universal design emerged from slightly earlier barrier-free concepts. Main assumptions of this idea was expounded by The Center for Universal Design at North Carolina State University as seven principles:

1. Equitable use (providing the same means of use for all users),

2. Flexibility in use (providing a choice in methods of use),

3. Simple and intuitive (eliminating unnecessary complexity and providing consistency with user expectations and intuition),

4. Perceptible information (using different modes for additional presentation of essential information and increasing its legibility),

5. Tolerance for error (arranging elements of design to minimize risk and errors and providing fail safe features),

6. Low physical effort (allowing user to maintain a neutral body position with minimum fatigue while using the design),

7. Size and space for approach and use (independently from user's body size or mobility provide adequate access, reach and use) [Helvacioglu and Karamanoglu 2012]. 
In Poland the problem of adjusting space for people with disabilities was only being taken into account after 1990 as a result of political changes. At that time, publications and regulations on this topic were published in professional literature and Polish legislation. As a result of these actions, the requirements of appropriate adjusting of the built environment in building code were introduced ${ }^{1}$. Whereas in Polish literature [Kuryłowicz 1996] the concept of universal design were introduced.

\section{Definition of architectural barriers}

In some Polish-language sources ${ }^{2}$ can be found many attempts to define the term 'architectural barrier', but these definitions are often incoherent. Their thematic scope is partially the same, but they are not sufficient in terms of a universal design. The utilize of this term is often limited to narrowing group of people with disabilities only to wheelchair users. This concept is also often limited only to the concept of an obstacle, so that some of the elements are excluded from the meaning of architectural barriers.

Broader view of the architectural barriers definition was proposed by A. Zając [2012] for the purpose of the project aiming at the creation of the Warszawska Mapa Barier ${ }^{3}$. Through its wide thematic scope it fits well into the idea of universal design. According to him, it could be any object in a public space that causes mobility problems or reduces access for any group of users (disabled, elderly, low and high persons, travelers, people with wheelchairs, pregnant women, cyclists etc.). However, these objects may also be associated with building objects, not only to public space.

\section{Types of barriers and ways of removing them}

In order to design a barrier-free space, it is important to recognize the features that could form barriers for some people so that the alternative spatial solutions can be proposed. In case of transforming existing space to make it accessible for people with disabilities, the ability to recognize barriers is also the key issue to be able to remove them. Of course thinking inclusively about the whole range of impairments needs to be done. Barriers existing in public space may be related to communication paths, overcoming height differences, entrances to the buildings, equipment elements and the infrastructures associated to transport [Zając et al. 2013]. After recognition, using appropriate design guidelines prepared on the basis of anthropometric patterns there could be designed a barrier-free space or transformed into accessible one by removing currently existing barriers. Below was placed the list of typical barriers and guidelines for the proper design of individual places in public space. Most commonly encountered barriers on the communication paths:

- bad technical condition,

- unhardened Surface,

- uneven or too slip surface,

too narrow sidewalks,

- lack of tactile paving for blind people.

Guidelines for removing these barriers:

- main pedestrian routes should be rectilinear and changes of its directions should be as close as it possible to the right angle;

- the longitudinal slope should not exceed $6 \%$ (to provide more comfort for people moving in wheelchair even 5\%), and cross slope maximum 2\% [Kowlaski 2010];

1 Rozporzadzenie Ministra Gospodarki Przestrzennej i Budownictwa z dnia 14 grudnia 1994 r. w sprawie warunków technicznych, jakim powinny odpowiadać budynki i ich usytuowanie; currently these regulations are included in Rozporzadzenie Ministra Infrastruktury z dnia 12 kwietnia 2002 r. w sprawie warunków technicznych, jakim powinny odpowiadać budynki i ich usytuowanie.

2 e.g. Encyklopedia PWN, Wikipedia, niepelnosprawni.pl, Encyklopedia WIEM - zapytaj.onet.pl, mapabarier.sisko.waw.pl

3 loosely translated as Warsaw Barrier Map 
- the path width should be not less than $150 \mathrm{~cm}$, (its allowing comfort manoeuvring of the wheelchair), it can be reduced to $120 \mathrm{~cm}$, if the length of this part does not exceed $20 \mathrm{~m}$;

- the width of main avenues with bigger traffic on both sides should be at least $200 \mathrm{~cm}$ to provide comfortable passing by [Kowalski 2011];

- the surface must be flat and rough enough to eliminate the possibility of stumbling or slipping [Czarnecki and Siemiński 2004];

- additional elements on surfaces - tactile paving, that have a different factures depending on its functions (attention, directional and warning) should be provided for the blind people in strategic places;

- it is recommended to use durable materials to provide good technical condition.

Most commonly encountered barriers related to overcoming height differences:

- lack of ramps or elevators at the stairs,

- too steep wheelchair ramps,

- unmarked lower and upper edges of stairs,

no handrail at the stairs,

- construction of steps in areas with a slight difference in terrain,

- bad technical condition.

Guidelines for removing these barriers:

a instead of designing stairs, a long smooth slopes should be planned when is impossible, when it is not, in addition to the stairs should be also included the ramps;

- usable width of the wheelchair ramp must be at least of $120 \mathrm{~cm}$;

- if it is necessary to use longer ramps, they should be divided into shorter sections (single section cannot exceed $9 \mathrm{~m}$ ) utilizing landings, that cannot be shorter than $1.4 \mathrm{~m}$, (in case of change direction, there should be ensured movement area with minimum dimensions of $1.5 \times 1.5 \mathrm{~m}$ );

- at the end and the beginning of the ramp, it has to be placed flat manoeuvring area;

- on both sides of the ramp should be designed a handrail at heights of $75 \mathrm{~cm}$ and $90 \mathrm{~cm}$, parallel to the surface [Budny 2009];

allowable slope of the ramp depends of the height differences and its location (outdoor or indoor);

- single steps should be avoided;

- in case of more than 10 steps in flight of stairs, there must be applied landings;

- the most comfortable steps are between 12 to $15 \mathrm{~cm}$ high and depth about $35 \mathrm{~cm}$;

- there is no need to design railings, when the height difference is less than $0,5 \mathrm{~m}$;

a flight of stairs should be at least of 1,2 $\mathrm{m}$, and the railings should be attached at of $90 \mathrm{~cm}$, (pair of railings at 75 and $90 \mathrm{~cm}$ is not obligatory) [Kowlaski 2010].

the first and last step should be marked with a contrasting stripe;

- it is recommended to design $0,5 \mathrm{~m}$ of tactile pavement (warning field) $0,6 \div 0,8 \mathrm{~m}$ before and after flight of stairs [Polski Związek Niewidomych 2009].

Most commonly encountered barriers related to space equipment:

- placement of elements within the sidewalks gauge,

- insufficient maneuvering space nearby the devices or lack of that,

- badly designed height of usable elements (too low or too high),

wrong placed or to weak lighting.

Guidelines for removing these barriers:

- equipment should be grouped together and form rows, that are parallel to the main axis of the path [NDA 2002];

- designed elements should not reduce the usable width of the path;

- information boards should be placed outside the paths and follow the rules of safe arrangement;

- parking meters should be placed to available for people with disabilities and its nearest space should be enough for manoeuvring; 
- functional parts of devices cannot be higher than arm of person in wheelchair can reach what is estimated as $130 \mathrm{~cm}$ maximally [Nowak and Budny 2008];

- important informations at the equipment in public space should be also written in braille language and the space before it should be marked by tactile pavement (field of attention);

- fountains must be separated from the pedestrian parts with utilizing belt of greenery or through the use of warning components.

Most commonly encountered barriers related to infrastructures associated to transport:

narrow bus stops;

bus stops with unpaved platforms;

badly designed bus bays (access to the edge of the platform is impossible);

- lack low curbs;

- unspecified passage through the road;

no warning tactile fields at the pedestrian crossings;

- pedestrian crossings without refuge islands on two-way multi-lane roads;

- lack of parking places dedicated to the disabled.

Guidelines for removing these barriers:

- car parks should contain wider $(3,6 \mathrm{~m})$ parking places for disabled (their amount depends on the amount of all places);

- curb higher than $2 \mathrm{~cm}$, should contain ramp with a maximally 5\% slope [Kowalski 2010];

- blind and visually impaired people needs tactile warning fields before pedestrian crossings in contrasting colour and located along the street with at least 0,5 $\mathrm{m}$ width;

- traffic light should make audible signal and include buttons that activate green light located on height from 0,9 to $1,1 \mathrm{~m}$ [Wysocki 2010];

- bus stop shed (with depth about $150-180 \mathrm{~cm}$ ) should be distant from the warning tactile paving min. $80 \mathrm{~cm}$ to allow passage of wheelchair;

actile warning lane over the entire length of the platform should be 30 or $40 \mathrm{~cm}$ wide at a distance of $80 \mathrm{~cm}$ from the edge of the platform;

- it is recommended to raise the platform to a height of $20 \mathrm{~cm}$ to make easier get in the bus for wheelchair users;

- the edge of the platform should be marked by contrast strip (yellow recommended) with a width of 7 or $10 \mathrm{~cm}$ on the entire platform length [Wysocki 2012];

The existence of barriers in public space also depends on the proper management of given space. Well planned accessibility may be lost over time due to lack of maintenance of key components. Seasons can also have influence of the space accessibility. Bad weather conditions can contribute to creation of new barriers, especially in the winter. To name a few, bad snow shoveling, snowdrifts and icy surfaces can be the big obstacles for disabled. Description of problematic aspects of this phenomenon can also be found in the literature of the subject, particularly in relation to wheelchair users [Joshi 2014, Ripat and Colatruglio 2006].

From one year to another in Poland is a noticeable increasing in awareness of sharing space with disabled people. This has a direct impact on the reduction of barriers in public space. As a result, there are government actions for people with disabilities. On the website of the Public Information Bulletin ${ }^{4}$ can be found information about the financing of actions to remove barriers from the funds of PFRON (State Fund for the Rehabilitation of the Disabled). There is a list of works aimed at removing specific barriers that may be funded. There are also described tips for submitting such projects and the forms uploaded together with instructions for their completion. Furthermore there a some other initiatives such as the Warszawska Mapa Barier created by the SISKOM Association (Association of the Integration of the Capital's Communication) or making accessibility standards for individual cities. 


\section{Conclusion}

In order to free the space from barriers, everything should be reviewed - from the whole structure to the smallest detail. Important thing is also seeking feedback from users and learning from mistakes, because the space sometimes is only seemingly available, it can be adapted but in a bad way. Many disadvantages of planning the accessibility in public spaces are the results of lack consistent requirements. From year to another it should change as it is in some Polish cities. Unification of law will certainly help to obligate the design offices to plan better accessibility in public procurements [Kowalski 2013]. The need for financial outlays to remove barriers can slow down the improvement of public space but every investment can be spread over the time. A progressive modernization may compensate high disposable costs and as a result, public space would gradually become more accessible [Rawski 2017].
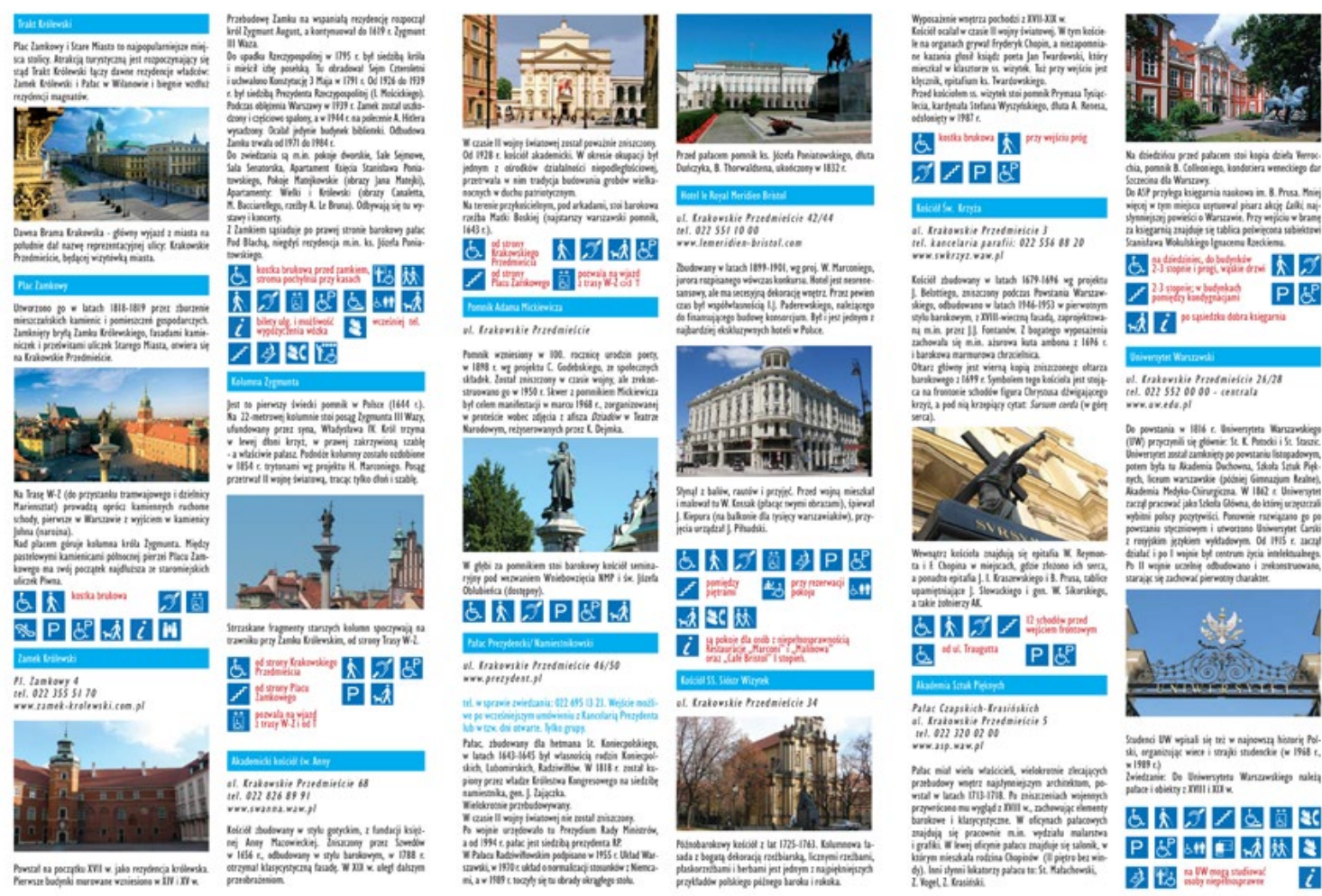

Fig. 1. Fragment of the guide for disabled tourists, (source: Stołeczne Biuro Turystyki)

As the result of removing barriers, especially in highly developed countries, people with disabilities are increasingly able to moving around the public space. Among the representatives of this social group are also people with greater than earlier financial capacity. It leads to opportunities to travel around the modern world. Even a new strategies in tourism are developing. Nowadays, there are carried out attempts to put barrier-free tourism for people with disabilities through selected areas in tourist regions which are suited to their mobility needs [Wang 2011]. There are also created a guides for such places (Fig. 1.), for those who want to travel on their own. This indicates that situation of people with disabilities is getting better. However, the integration process cannot be considered as finished until it completely ceases to exist as a phenomenon of social exclusion. This is a multidimensional process where spatial planning is only one of elements.

Note. The article was prepared in frames of the statutory work S/WBilS/2/2016 realized by KKBiA, WBilŚ, PB 


\section{References}

[1] Adach-Stankiewicz E. et al., 2012. Narodowy Spis Powszechny Ludności i Mieszkań 2011, Raport z wyników, Zakład Wydawnictw Statystycznych, Warszawa.

[2] Barczyński P. G., 2011. Udostępnianie przestrzeni publicznych dla wszystkich, ze szczególnym uwzględnieniem osób z niepełnosprawnością, Inżynier Budownictwa - Prawo [online] http://www.inzynierbudownictwa.pl/biznes,prawo,arty kul,udostepnianie_przestrzeni_publicznych_dla_wszystkich_ze_szczegolnym_uwzglednieniem_osob_z_niepelnosprawnoscia,4885 (access: 30.10.2017).

[3] Budny J., 2009. Dostosowanie budynków użyteczności publicznej - teoria i narzędzia, Stowarzyszenie Przyjaciół Integracji, Warszawa.

[4] Czarnecki B., Siemiński W., 2004. Kształtowanie bezpiecznej przestrzeni publicznej, Difin, Warszawa.

[5] Helvacioglu E., Karamanoglu N. N., 2012. Awareness of the concept of universal design in design education, Procedia Social and Behavioral Sciences, Vol.51, pp. 99-103.

[6] Joshi D., 2014. Winter"n"Wheels study: Understanding experiences of key stakeholder groups regarding sidewalks accessibility in winter for wheeled mobility device users, A Thesis submitted to the Faculty of Graduate Studies of the University of Manitoba, [online] http://hdl.handle.net/1993/24165 (access: 18.11.2017).

[7] Kowalski K., 2010. Projektowanie bez barier - wytyczne, Stowarzyszenie Przyjaciół Integracji, Warszawa.

[8] Kowalski K., 2011. Planowanie dostępności - prawo w praktyce, Stowarzyszenie Przyjaciół Integracji, Warszawa.

[9] Kowalski K., 2013. Accessibility planning - Polish legal status and practice (in Polish), Niepełnosprawność - zagadnienia, problemy, rozwiązania. Nr I/2013(6), pp. 71-99.

[10] Kuryłowicz E., 1996. Projektowanie uniwersalne. Udostępnianie otoczenia osobom niepełnosprawnym, Centrum Badawczo-Rozwojowe Rehabilitacji Osób Niepełnosprawnych, Warszawa.

[11] NDA, 2002. Building for Everyone: Inclusion, Access and Use, National Disability Authority, Dublin.

[12] Nowak E., Budny J, 2008. Mieszkanie dostępne dla osób z dysfunkcją narządu ruchu, Stowarzyszenie Przyjaciół Integracji, Warszawa.

[13] Osman M. M., Radzi, F. H. M., Bakri, N. I. M., \& Ibrahim, M., 2015. Barrier-free Campus: University Malaya, Kuala Lumpur, Procedia - Social and Behavioural Sciences, 168, pp. 134144.

[14] Polski Związek Niewidomych, 2009. Osoby niewidome i słabo widzące w przestrzeni publicznej, Warszawa.

[15] Rawski K., 2017. Accessibility of the urban green areas for people with disabilities on the example of Planty Park in Białystok, Poland, "Formation of urban green areas - Scientific Articles", 1(14), p. 179-185.

[16] Ripat J., Colatruglio A., 2006. Exploring Winter Community Participation Among Wheelchair Users: An Online Focus Group, Occupational Therapy In Health Care, 30/1, pp. 95-106.

[17] Tytyk E., 2011. Projektowanie ergonomiczne, PWN, Warszawa.

[18] Wang L., 2011. Strategies of Disabled Person's Barrier-free Tourism Based on Supply-Demand Relationship, IEEE, pp. 4773-4775

[19] Wysocki M., 2010. Projektowanie otoczenia dla osób niewidomych. Pozawzrokowa percepcja przestrzeni, Wydawnictwo Politechniki Gdańskiej, Gdańsk.

[20] Wysocki M., 2012. Standardy dostępności dla miasta Gdyni, Gdynia.

[21] Zając A. P., 2012. Miasto barier. Bariery architektoniczne na podstawie projektu Warszawska Mapa Barier, Instytut Socjologii UW, SISKOM, [online] http://mapabarier.siskom.waw.pl/wp-content/uploads/2012/05/Zajac_bariery_architektoniczne_KMS2012.pdf (dostęp: 30.10.2017).

[22] Zając A. P., Dębska M., Kowalski R., Pietrzyk P., Rak. A., Zakrzewski M., 2013. Diagnoza głównych barier architektonicznych w przestrzeni publicznej Warszawy - Raport SISKOM, SISKOM, Warszawa.

[23] Złowodzki M., 2008. O Ergonomii i Architekturze, Wydawnictwo Politechniki Krakowskiej, Kraków.

\section{Websites}

[24] Public Information Bulletin (pl. Biuletyn Informacji Publicznej), http://www.bip.mopr.gda.pl/index. php?idg=1\&id $=174 \& x=25 \& y=2$ (access: 8.11.2017).

[25] Sprawny Fachowiec, 2015. Bariery architektoniczne dla osób niepełnosprawnych, http://www.sprawnyfachowiec.pl/ artykul/516/bariery-architektoniczne-dla-osob-niepelnosprawnych (access: 30.10.2017). 
[26] United Nations, 1982. World Programme of Action Concerning Disabled Persons, https://www.un.org/development/ desa/disabilities/resources/world-programme-of-action-concerning-disabled-persons.html (access: 12.11.2017).

[27] World Health Organization, http://www.who.int/topics/disabilities/en/ (access: 12.11.2017).

\section{Przestrzeń publiczna bez barier architektonicznych, jako przyjazna dostępna dla osób niepełnosprawnych}

Streszczenie: Dostępna przestrzeń publiczna z punktu widzenia osób niepełnosprawnych to taka, w której nie występują bariery uniemożliwiające im normalnego funkcjonowania w danym miejscu. W niniejszej pracy zebrano szereg wytycznych projektowych potrzebnych do zaplanowania dostępnej przestrzeni oraz typowe dla przestrzeni publicznej bariery. Omówiono także typy barier architektonicznych oraz czynniki wpływające na dostępność przestrzeni.

Słowa klucze: projektowanie uniwersalne, projektowanie dla niepełnosprawnych, dostępność, przestrzeń publiczna, bariery architektoniczne 